\title{
Daily growth rate model of Japanese anchovy larvae Engraulis japonicus in Hiuchi-nada Sea, central Seto Inland Sea
}

\author{
Hiromu Zenitani • Naoaki Kono
}

Received: 22 December 2011/Accepted: 28 June 2012/Published online: 31 July 2012

(C) The Author(s) 2012. This article is published with open access at Springerlink.com

\begin{abstract}
In the present study, we developed a larval anchovy growth model in relation to sea temperature and food availability via food consumption and metabolic process terms, based on biological data from previous laboratory experiments and field surveys from 2003 to 2006 in Hiuchi-nada Sea, central part of Seto Inland Sea, Japan. To investigate when food shortage for larval anchovy and then recruitment failure occur in Hiuchi-nada Sea, anchovy food requirements were estimated by using the growth model, and we compared the food requirement with anchovy food availability. We applied an estimation method for growth model parameters, Hewett-Johnson $p$ and $Q_{10}$, by minimizing the sum of squares of difference between mass-specific growth rates estimated by the models and those by otolith growth analysis. Parameter $p$ was 0.86 , slightly higher than typical values, and $Q_{10}$ was 2.11 , close to the value used for the biological model of larval northern anchovy. Food shortage for anchovy larvae did not occur in Hiuchi-nada Sea, although it was indicated that low food availability led to a low reproductive success rate. The newly developed growth model is considered optimal at present and useful to link environmental conditions and larval growth.
\end{abstract}

Keywords Anchovy larvae · Growth model · Hiuchi-nada Sea · Otolith growth analysis · Seto Inland Sea

H. Zenitani $(\square) \cdot$ N. Kono

National Research Institute of Fisheries and Environment

of Inland Sea, Fisheries Research Agency, Hatsukaichi,

Hiroshima 739-0452, Japan

e-mail: zenitani@affrc.go.jp

\section{Introduction}

The Seto Inland Sea is well known for its high fish production [1]. Japanese anchovy Engraulis japonicus is an important commercial species, accounting for $34 \%$ of the total fish production of $67 \times 10^{3}$ tons in the Seto Inland Sea in 2009. Hiuchi-nada Sea is located in the central part of the Seto Inland Sea between Kurushima Strait and Bisan Strait, a semi-enclosed narrow sea (Fig. 1). It has a size of about $50 \times 30 \mathrm{~km}^{2}$ and an average depth of about $20 \mathrm{~m}$, being a major spawning and fishing ground of Japanese anchovy. Total catch of anchovy in Hiuchi-nada Sea was $15 \times 10^{3}$ tons in 2005 , accounting for $27 \%$ of the total anchovy catch in the entire Seto Inland Sea. In this area, forecasting the degree of recruitment populations of shirasu (larval anchovy in Japanese, body length: ca. $20-35 \mathrm{~mm}$ ) to the fishery stock is required for efficient exploitation [2]. Recruitment forecasting however has generally not been successful [3], because it is difficult to forecast the survival rate (or mortality rate) from the prerecruitment stage to the recruitment stage.

In recent years, individual-based models have been developed to understand how physical or biological factors affect larval anchovy survival or recruitment [4-6]. These models require algorithms for the growth process. In Zenitani et al. [2], the authors already found that the growth rate for larval anchovy was dependent on temperature, food availability, and larval size. However, a detailed growth model to describe the relation to sea temperature and food availability has not been developed for larval anchovy in the Seto Inland Sea. The aims of the present study are to (1) develop a larval anchovy growth model in relation to sea temperature and food availability via food consumption and metabolic process terms in Hiuchi-nada 
Fig. 1 Survey stations of plankton sampling in Hiuchinada Sea, Seto Inland Sea, Japan

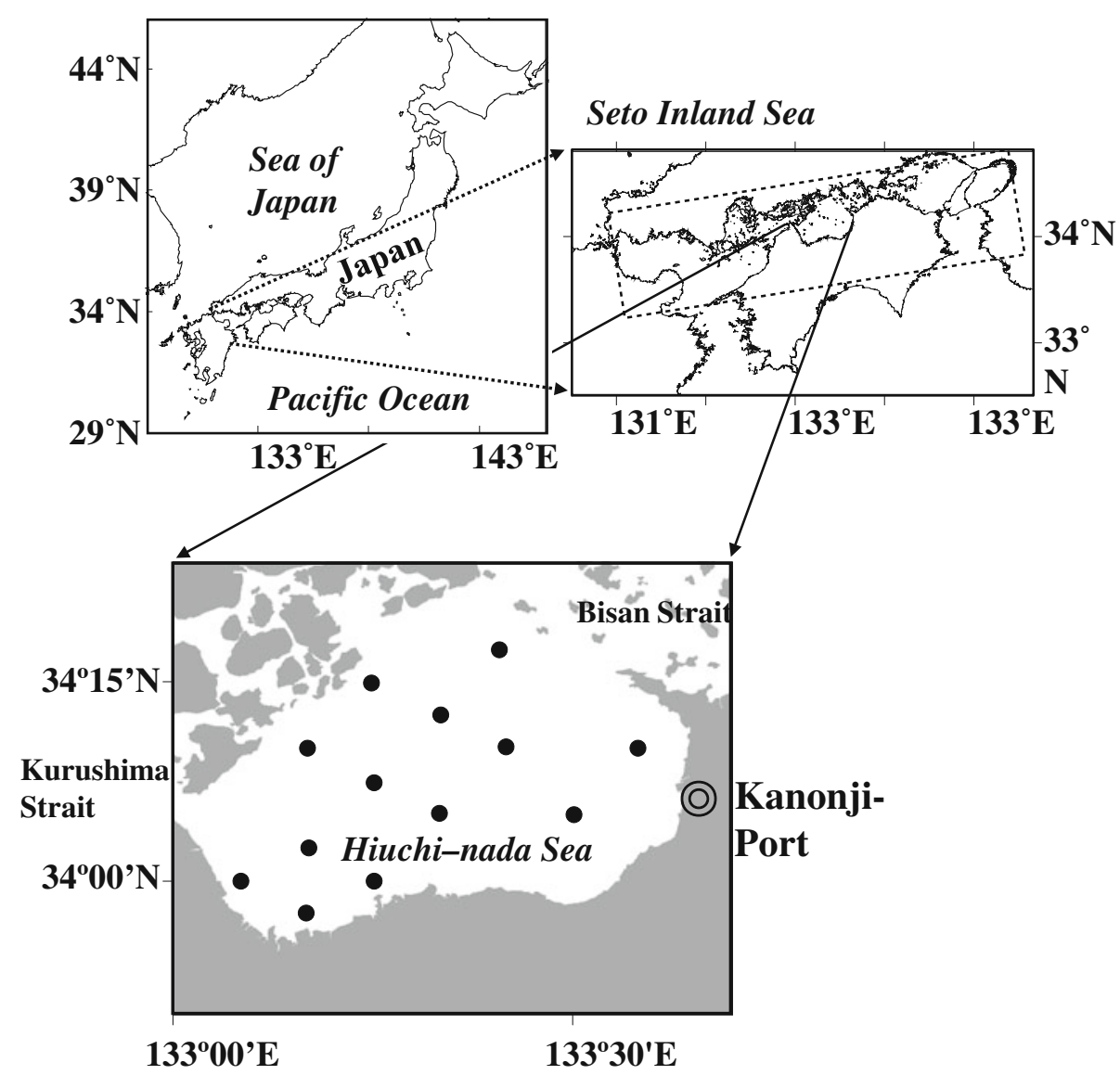

Sea and (2) investigate if a food shortage for larval anchovy occurs and detect any recruitment failure of yearclass in this study area. We developed a growth model for larval anchovy, based mainly on information from Japanese anchovy and northern anchovy E. mordax. In the past, anchovy were popular experimental organisms, cultured to understand their growth [7, 8], physiology [9], capacity to survive starvation [10], and swimming behavior [2, 11]. Yokota et al. [12] and Uotani [13] studied feeding behavior in the Seto Inland Sea or waters along the Pacific coast of Japan. These studies provide a rich source of information which can be used to formulate and calibrate the growth model. This manuscript presents a method for estimating parameters of the growth model by linking otolith growth analysis, laboratory experiments, and field survey data in Hiuchi-nada Sea.

A possible key factor in the regulation of anchovy population levels is the fluctuations in abundance of the copepod assemblage, and the crucial period for recruitment of anchovy in Hiuchi-nada Sea would be the period just before the anchovy recruitment to the shirasu fishery [14]. To investigate when food shortage for larval anchovy and recruitment failure occur in Hiuchi-nada Sea, anchovy food requirements were estimated by using the growth model, and we compared the food requirement with anchovy food availability in Hiuchinada Sea.

\section{Materials and methods}

Otolith growth

The mass-specific growth rate of an individual anchovy $l$ was determined by otolith growth analysis, as follows [2]:

Anchovy were sampled from commercial catches (seine net fishery) at Kanonji Port in Hiuchi-nada Sea (Fig. 1) on 18 July 2003, 6 July and 6 August 2004, 27 June 2005, and 24 June 2006. A subsample of 50-100 anchovy larvae and juveniles was taken randomly from each commercial catch and preserved in $99 \%$ ethanol. Each fish was measured for standard length (SL) to the nearest $0.1 \mathrm{~mm}$ with digital calipers. Sagittal otoliths of the larvae and juveniles (30.2-44.6 mm SL in 2003, 37.4-64.5 mm SL in 2004, 17.7-33.0 mm SL in 2005, 23.7-32.0 mm SL in 2006) were dissected out, cleaned under a binocular dissecting microscope, and mounted on a glass slide with epoxy resin. Measurement of otolith daily increments was conducted 
along core-posterior margin axis using the otolith measurement system (Ratoc System Engineering Inc., Tokyo, Japan) under a light microscope at 100-200× magnification.

When the relation between otolith radius and fish size is predictable, growth rates can be calculated based on otolith increment widths [2, 15-18]. According to previous experimental studies on Japanese anchovy, the daily growth increment is deposited at the start of external feeding, 3-4 days after hatching [8], and SL at completion of yolk absorption is $5.6 \mathrm{~mm}$ [19]. Daily age of each anchovy was calculated, therefore, as the number of rings plus 3. SL at each daily age was back-calculated by the biological intercept method [20, 21], with SL at the first deposition of the daily growth increment fixed at $5.6 \mathrm{~mm}$ as the biological intercept at the individual level. We assumed that the relationship of otolith radius $\operatorname{OR}(l, m)$ $(\mu \mathrm{m})$ and SL $\left[=L_{\mathrm{a}}(l, m)(\mathrm{mm})\right]$ of individual anchovy $l$ of the $m$ th ring formation can be expressed by an allometric formula for the individual. Hence, $L_{\mathrm{a}}(l, m)$ of each anchovy was back-calculated by substituting $\operatorname{OR}(l, m)(\mu \mathrm{m})$ for $L_{\mathrm{a}}(l$, $m$ ) using the allometric relationship,

$L_{\mathrm{a}}(l, m)=a(l) \times \mathrm{OR}(l, m)^{b(l)}$,

where $a(l)$ and $b(l)$ are parameters determined for each anchovy by solving the two equations

$L_{\mathrm{a}}(l, 1)=a(l) \times \mathrm{OR}(l, 1)^{b(l)}$

and

$L_{\mathrm{a}}\left(l, m_{\max }(l)\right)=a(l) \times \mathrm{OR}\left(l, m_{\max }(l)\right)^{b(l)}$,

where $m_{\max }(l)$ is the maximum number of rings of individual anchovy $l$, and $L_{\mathrm{a}}(l, 1)$ of $5.6 \mathrm{~mm}, \mathrm{OR}(l, 1), L_{\mathrm{a}}(l$, $\left.m_{\text {max }}(l)\right)$, and $\operatorname{OR}\left(l, m_{\max }(l)\right)$ are the SL at the first daily growth increment deposition, measured radius of the first daily ring, SL at sampling day $d_{\mathrm{s}}(l)$, and measured radius at sampling day $d_{\mathrm{s}}(l)$, respectively.

The relationship between body mass, $W_{\mathrm{a}}(l, m)(\mathrm{mgC})$, and SL of Japanese anchovy larvae [22] has been found as

$W_{\mathrm{a}}(l, m)=2.045 \times 10^{-4} \times L_{\mathrm{a}}(l, m)^{3.385} \times 0.43$,

where 0.43 is a multiplier to convert to carbon weight from dry weight [23].

The mass-specific growth rate $\hat{G}(l, m(i, l)) \quad\left(\right.$ day $\left.^{-1}\right)$ for individual anchovy $l$ at $m(i, l)$ th ring formation was estimated from the change in the back-calculated weight for individual anchovy $l$ in plankton survey cruise $i$ as

$\hat{G}(l, m(i, l))=\frac{W_{\mathrm{a}}(l, m(i, l)+\Delta t)-W_{\mathrm{a}}(l, m(i, l))}{\Delta t \times W_{\mathrm{a}}(l, m(i, l))}$, $m(i, l)=m_{\max }(l)-\left(d_{\mathrm{s}}(l)-d_{\mathrm{c}}(i)\right) \times$ number of rings $\times$ day $^{-1}$

where $d_{\mathrm{c}}(i)$ is the first day of plankton survey cruise $i$. In our study, $\Delta t$ is the period of time for a cruise, $\Delta t=$ 3 days. The metamorphosing stage of Japanese anchovy, defined as the stage of guanine deposition on the peritoneal and trunk surface, occurs from 31 to $37 \mathrm{~mm} \mathrm{SL}$, while the juvenile stage occurs from ca. $40 \mathrm{~mm}$ SL [24]. Based on this study of anchovy development stages, we supposed a larval-stage SL range of 5.6-31.0 mm, and then estimated the growth rate in this range.

Plankton survey

From spring to early summer, in 2003-2006, a total of 14 daytime cruises of R.V. Shirafuji maru, National Research Institute of Fisheries and Environment of Inland Sea, were conducted to sample plankton at 13 stations over 4-day survey periods, as follows (Fig. 1; Table 1, Zenitani et al. [2]):

At each station, a hydrographic cast was made using a Niel Brown CTD (Cataumet, MA, USA) in 2003 and a compact CTD (ACL 208-PDK Alec Electronics, Kobe, Japan) in 2004-2006. Water samples for determining copepod nauplii density were collected with a 20-1 Van Dorn water sampler (Rigo, Tokyo, Japan) from $10 \mathrm{~m}$ depth. Since previous studies in Seto Inland Sea [25, 26] have demonstrated that larval anchovies are distributed mainly in the 5-20 m depth strata, predominantly at $10 \mathrm{~m}$ depth, we selected $10 \mathrm{~m}$ as a representative depth.

For copepod nauplii abundance, 11 of the water sample was filtered aboard with a cellulose nitrate membrane filter (pore size $5.0 \mu \mathrm{m}$; Toyo Roshi Kaisha, Tokyo, Japan), and copepod nauplii on the filters were resuspended and preserved in 5-10\% formalin in a 10-ml test tube. After nauplii were stained by adding $0.1-0.2 \mathrm{ml}$ Rose Bengal, they were enumerated on a counting plate. Body length was measured for all the nauplii.

Copepods (copepodites and adults) were collected with a plankton net (mouth diameter $0.45 \mathrm{~m}$, length $1.95 \mathrm{~m}$, mesh opening $100 \mu \mathrm{m}$, fitted with a Rigosha flowmeter; Rigo), which was pulled vertically from $2 \mathrm{~m}$ above the sea bottom to the surface. After the net was retrieved, the zooplankton were immediately preserved in 5-10\% formalin-sea water solution. Later the sample was split into 1/ 32-1/256 subsamples, from which copepods were enumerated under a stereoscopic microscope. To estimate the length-frequency distribution from cruise $i$, up to 100 copepods for each genus were randomly sorted from each sample and their prosome length was measured to the nearest $0.1 \mathrm{~mm}$. 
Table 1 Mean temperature, copepod nauplii abundance, small-size (0.25-0.50 mm prosome length) copepod abundance, and large-size (over $0.50 \mathrm{~mm}$ prosome length) copepod abundance in Hiuchi-nada Sea in 2003-2006

\begin{tabular}{|c|c|c|c|c|c|}
\hline Cruise & Date & $\begin{array}{l}\text { Mean temperature } \\
( \pm \text { SD })\left({ }^{\circ} \mathrm{C}\right)\end{array}$ & $\begin{array}{l}\text { Copepod nauplii } \\
\text { mean concentration } \\
( \pm \mathrm{SD}) \\
\left(10^{3} \text { individuals } \mathrm{m}^{-3}\right)\end{array}$ & $\begin{array}{l}\text { Small-size copepods } \\
\text { mean concentration } \\
( \pm \mathrm{SD}) \\
\left(10^{3} \text { individuals } \mathrm{m}^{-3}\right)\end{array}$ & $\begin{array}{l}\text { Large-size copepods } \\
\text { mean concentration } \\
( \pm \mathrm{SD}) \\
\left(10^{6} \text { individuals } \mathrm{m}^{-3}\right)\end{array}$ \\
\hline 1 & 21-24 May 2003 & $16.3 \pm 0.5$ & $33.2 \pm 17.6$ & $12.3 \pm 37.4$ & $3.4 \pm 18.5$ \\
\hline 2 & 11-14 June 2003 & $19.0 \pm 0.4$ & $22.8 \pm 12.9$ & $19.8 \pm 62.5$ & $1.6 \pm 8.8$ \\
\hline 3 & 27-30 June 2003 & $20.8 \pm 0.8$ & $25.1 \pm 13.3$ & $12.2 \pm 36.9$ & $2.2 \pm 12.1$ \\
\hline 4 & 6-9 May 2004 & $15.9 \pm 0.6$ & $15.5 \pm 9.4$ & $11.3 \pm 35.0$ & $2.9 \pm 15.8$ \\
\hline 5 & 18-21 May 2004 & $17.5 \pm 0.6$ & $23.8 \pm 12.7$ & $14.7 \pm 44.8$ & $2.2 \pm 12.0$ \\
\hline 6 & 6-9 June 2004 & $19.8 \pm 0.6$ & $16.2 \pm 9.0$ & $4.5 \pm 13.7$ & $0.4 \pm 2.0$ \\
\hline 7 & 1-4 July 2004 & $22.5 \pm 0.7$ & $18.9 \pm 9.8$ & $5.0 \pm 15.5$ & $1.1 \pm 5.9$ \\
\hline 8 & 13-16 July 2004 & $24.3 \pm 0.9$ & $52.9 \pm 17.8$ & $20.9 \pm 64.2$ & $2.1 \pm 11.1$ \\
\hline 9 & 9-12 May 2005 & $15.7 \pm 0.6$ & $23.0 \pm 15.1$ & $11.0 \pm 34.1$ & $2.4 \pm 12.9$ \\
\hline 10 & 19-22 May 2005 & $16.7 \pm 0.5$ & $34.6 \pm 20.5$ & $13.3 \pm 41.4$ & $2.8 \pm 15.1$ \\
\hline 11 & 6-9 June 2005 & $18.3 \pm 0.5$ & $38.3 \pm 23.1$ & $20.0 \pm 61.2$ & $3.6 \pm 19.2$ \\
\hline 12 & 22-25 June 2005 & $20.4 \pm 0.9$ & $25.1 \pm 13.3$ & $19.8 \pm 60.3$ & $1.9 \pm 10.1$ \\
\hline 13 & 23-26 May 2006 & $15.6 \pm 0.6$ & $15.2 \pm 10.1$ & $8.1 \pm 24.5$ & $2.4 \pm 12.6$ \\
\hline 14 & 13-16 June 2006 & $18.4 \pm 0.5$ & $16.6 \pm 9.7$ & $10.4 \pm 31.9$ & $2.3 \pm 12.2$ \\
\hline
\end{tabular}

We classified the copepods into three stages

$j= \begin{cases}1 & \text { nauplius stage }(<0.25 \mathrm{~mm} \text { in body length }) \\ 2 & \text { small-size stage }(0.25-0.50 \mathrm{~mm} \text { in prosome length, mode } 0.37 \mathrm{~mm}) \\ 3 & \text { large-size stage }(>0.50 \mathrm{~mm} \text { in prosome length })\end{cases}$

We calculated the mean body length $L_{\mathrm{c}}(i, 1)(\mathrm{mm})$ for a copepod nauplii from cruise $i$, and then the carbon content $W_{\mathrm{c}}(i, 1)(\mathrm{mgC})$ was calculated from the mean body length as [27]

$W_{\mathrm{c}}(i, 1)=1.51 \times 10^{-14} \times\left(L_{\mathrm{c}}(i, 1) \times 10^{3}\right)^{2.94}$.

Prosome length $L_{\mathrm{c}}(i, j, k)(\mathrm{mm})$ of taxonomic group $k$ of stage $j(=2,3)$ of copepod from cruise $i$ was converted to body carbon weight using the length-carbon weight regression equation [23, 28, 29]

$W_{\mathrm{c}}(i, j, k)=10^{-c(k)} \times 10^{-3} \times\left(L_{\mathrm{c}}(i, j, k) \times 10^{3}\right)^{d(k)}$.

$W_{\mathrm{c}}(i, j, k)(\mathrm{mgC})$ is the carbon weight of taxonomic group $k$ of stage $j$ of copepod from cruise $i$. The taxonomic groups were $k=1$, Acartia; $k=2$, Calanus; $k=3$, Centropages; $k=4$, Microsetella; $k=5$, Oithona; $k=6$, Paracalanus; $k=7$, others (Corycaeus, Oncaea, etc.). $c(k)$ and $d(k)$ are parameters of the taxonomic group $k$ (Tables 2; Zenitani et al. [2]).

We set the mean length of stage 2 copepods, $L_{\mathrm{c}}(i, 2, k)$, at $0.37 \mathrm{~mm}$, and calculated the mean length $L_{\mathrm{c}}(i, 3)(\mathrm{mm})$ in stage 3 copepods and mean weight $W_{\mathrm{c}}(i, j)(\mathrm{mgC})$ in stage 2 and 3 copepods by the following equations:

$$
\begin{aligned}
L_{\mathrm{c}}(i, 3) & =\frac{\sum_{k=1}^{7}\left(L_{\mathrm{c}}(i, j, k) \times A_{\mathrm{c}}(i, j, k)\right)}{\sum_{k=1}^{7} A_{\mathrm{c}}(i, j, k)}, \\
W_{\mathrm{c}}(i, j) & =\frac{\sum_{k=1}^{7}\left(W_{\mathrm{c}}(i, j, k) \times A_{\mathrm{c}}(i, j, k)\right)}{\sum_{k=1}^{7} A_{\mathrm{c}}(i, j, k)} \quad(j=2,3),
\end{aligned}
$$

where $A_{\mathrm{c}}(i, j, k)\left(10^{3}\right.$ individuals $\left.\mathrm{m}^{-3}\right)$ is the mean abundance of taxonomic group $k$ of stage $j$ of copepod from cruise $i$.

\section{Consumption}

The mass-specific food consumption rate was determined by an individual-based model for each individual anchovy of given size at a temperature and abundance of prey as follows (Fig. 2; Zenitani et al. [2]):

Copepods are the main prey items for anchovy larvae. At the first feeding stage, larval anchovy eat mainly 
Table 2 Parameters of regression equation of carbon weight against length for copepods collected in the Seto Inland Sea

\begin{tabular}{llll}
\hline$k$ & Taxonomic group & $c(k)$ & $d(k)$ \\
\hline 1 & Acartia & 8.51 & 3.08 \\
2 & Calanus & 7.00 & 2.64 \\
3 & Centropages & 8.19 & 2.97 \\
4 & Microsetella & 5.58 & 1.95 \\
5 & Oithona & 3.90 & 1.13 \\
6 & Paracalanus & 8.45 & 3.13 \\
7 & Others (Corycaeus, Oncaea, etc.) & 8.37 & 3.07 \\
\hline
\end{tabular}

naupliar copepods, then with increasing size, the larvae eat copepodites and adult copepods $[12,30]$. The food availability $C_{\mathrm{c}}(l, m(i, l)) \quad\left(\mathrm{mgC}\right.$ day $\left.^{-1}\right)$ of individual anchovy $l$ on copepods at $m(i, l)$ th ring formation was calculated as

$C_{\mathrm{c}}(l, m(i, l))=\sum_{j=1}^{3}\left(E_{\mathrm{m}}(i, j, l) \times W_{\mathrm{c}}(i, j)\right)$,

where $E_{\mathrm{m}}(i, j, l)$ is the number of encounters between stage $j$ copepods and individual anchovy $l$ that resulted in successful capture of stage $j$ copepods during cruise $i$. The number of encounters $E(i, j, l)\left(\right.$ day $\left.^{-1}\right)$ between stage $j$ copepods and individual anchovy $l$ in cruise $i$ was based on the Gerritsen and Strickler [31] model for randomly moving organisms in a three-dimensional space, such that

$$
E(i, j, l)=\left\{\begin{array}{c}
\pi \times D_{\mathrm{E}} \times C_{\mathrm{E}} \times A_{\mathrm{c}}(i, j) \times R_{\mathrm{T}}(i, j, l)^{2} \\
\times\left(\frac{3 \times V_{\mathrm{a}}(i, l)^{2}+V_{\mathrm{c}}(j)^{2}}{3 \times V_{\mathrm{a}}(i, l)}\right) \\
\text { for } V_{\mathrm{a}}(i, l) \geq V_{\mathrm{c}}(j) \\
\pi \times D_{\mathrm{E}} \times C_{\mathrm{E}} \times A_{\mathrm{c}}(i, j) \times R_{\mathrm{T}}(i, j, l)^{2} \\
\times\left(\frac{3 \times V_{\mathrm{c}}(j)^{2}+V_{\mathrm{a}}(i, l)^{2}}{3 \times V_{\mathrm{c}}(j)}\right) \\
\text { for } V_{\mathrm{c}}(j)>V_{\mathrm{a}}(i, l)
\end{array}\right.
$$

where $D_{\mathrm{E}}$ is the proportion of daylight hours in a day (12/ $24 \mathrm{~h}), C_{\mathrm{E}}$ is a conversion factor $\left(8.64 \times 10^{-4} \mathrm{~s} \mathrm{day}^{-1}\right)$, $A_{\mathrm{c}}(i, j)$ (individuals $\left.\mathrm{m}^{-3}\right)$ is the abundance of stage $j$ copepods from cruise $i$,

$A_{\mathrm{c}}(i, j)=\sum_{k=1}^{7} A_{\mathrm{c}}(i, j, k)$,

and $R_{\mathrm{T}}(i, j, l)(\mathrm{mm})$ is the total encounter radius. $V_{\mathrm{a}}(i, l)$ $\left(\mathrm{mm} \mathrm{s}^{-1}\right)$ and $V_{\mathrm{c}}(j)\left(\mathrm{mm} \mathrm{s}^{-1}\right)$ are the swimming speeds of individual anchovy $l$ in cruise $i$ and stage $j$ copepods, respectively. The total encounter radius was assumed to be equal to the sum of the mean encounter radius $R_{\mathrm{c}}(i, j)(\mathrm{mm})$ of stage $j$ copepods and the mean encounter radius $R_{\mathrm{a}}(i, l)$ (mm) of individual anchovy $l$ in cruise $i$, as Bailey and Batty [32] estimated,

$R_{\mathrm{T}}(i, j, l)=R_{\mathrm{c}}(i, j)+R_{\mathrm{a}}(i, l)$,

$R_{\mathrm{c}}(i, j)=\frac{2 \times L_{\mathrm{c}}(i, j)}{\pi^{2}}$,

$R_{\mathrm{a}}(i, l)=\frac{2 \times L_{\mathrm{a}}(l, m(i, l))}{\pi^{2}}$.

The swimming speed $V_{\mathrm{a}}(i, l)\left(\mathrm{mm} \mathrm{s}^{-1}\right)$ of individual anchovy $l$ in cruise $i$ was calculated as

$V_{\mathrm{a}}(i, l)=L_{\mathrm{a}}(l, m(i, l)) \times(0.076 \times T(i)-0.52)$,

where $T(i)\left({ }^{\circ} \mathrm{C}\right)$ is the mean water temperature at $10 \mathrm{~m}$ depth in cruise $i$ in Hiuchi-nada Sea (Zenitani et al. [2]).

The average swimming speed of the copepod Temora longicornis was $1.5 \mathrm{~mm} \mathrm{~s}^{-1}$ for nauplii and young copepodid stage $\left(<0.4 \mathrm{~mm}\right.$ in body length), about $5 \mathrm{~mm} \mathrm{~s}^{-1}$ in female adult stage, and $9 \mathrm{~mm} \mathrm{~s}^{-1}$ in male adult stage [33]. According to Yen [34], Euchaeta rimana has a typical swimming speed of roughly $7 \mathrm{~mm} \mathrm{~s}^{-1}$. We assumed that the swimming speed in the nauplii, small copepods, and large copepods was $1.5,1.5$, and $7 \mathrm{~mm} \mathrm{~s}^{-1}$, respectively.

The number of encounters between stage $j$ copepods and individual anchovy $l$ in cruise $i$, in which individual anchovy $l$ successfully captured stage $j$ copepods, was determined from a binomial distribution $B_{N}(E(i, j, l), P(i, j, l))$, and the mean number of encounters $E_{\mathrm{m}}(i, j, l)\left(\right.$ day $\left.^{-1}\right)$ is

$E_{\mathrm{m}}(i, j, l)=E(i, j, l) \times P(i, j, l)$,

where $P(i, j, l)$ is the capture success probability of individual anchovy $l$ for stage $j$ copepods in cruise $i$

$P(i, j, l)=\left\{\begin{array}{l}1 \text { for } L_{\min }(i, l) \leq L_{\mathrm{c}}(i, j) \leq L_{\max }(i, l) \\ 0 \text { for } L_{\mathrm{c}}(i, j)<L_{\min }(i, l) \text { or } L_{\max }(i, l)<L_{\mathrm{c}}(i, j) .\end{array}\right.$

The minimum and maximum length of copepods that anchovy larvae were able to capture, $L_{\min }(i, l)(\mathrm{mm})$ and $L_{\max }(i, l)(\mathrm{mm})$, were

$L_{\min }(i, l)= \begin{cases}0.15 & \text { for } 5.6 \mathrm{~mm} \leq L_{\mathrm{a}}(l, m(i, l))<9.0 \mathrm{~mm} \\ 0.20 & \text { for } 9.0 \mathrm{~mm} \leq L_{\mathrm{a}}(l, m(i, l))\end{cases}$

and

$L_{\max }(i, l)=0.434 \times \exp \left(0.105 \times L_{\mathrm{a}}(l, m(i, l))\right)$,

after Fig. 5-1 in Yokota et al. [12] and Fig. 6 in Uotani [13].

The mass-specific food consumption rate $C(l, m(i, l))$ $\left(\right.$ day $^{-1}$ ) of individual anchovy $l$ on copepods at $m(i, l)$ th ring formation is defined as a function of feeding rate for copepods and a proportionality constant parameter, Hewett-Johnson $p$ value [35], having values of zero to one. 
Table 3 Back-calculated mass-specific growth rate and food availability of anchovy in Hiuchi-nada Sea in 2003-2006

\begin{tabular}{|c|c|c|c|c|c|c|c|}
\hline Cruise & Date & $\begin{array}{l}\text { Sampling } \\
\text { or back- } \\
\text { calculation }\end{array}$ & $\begin{array}{l}\text { Mass-specific growth } \\
\text { rate as weight } \\
\text { increment per unit } \\
\text { weight }( \pm \mathrm{SD}) \\
\left(\text { day }^{-1}\right)\end{array}$ & $\begin{array}{l}\text { Mass-specific } \\
\text { food availability } \\
\text { per unit weight } \\
( \pm \text { SD })\left(\text { day }^{-1}\right)\end{array}$ & $\begin{array}{l}\text { Back- } \\
\text { calculated } \\
\text { SL }( \pm \text { SD })\end{array}$ & $\begin{array}{l}\text { Ratio of food } \\
\text { availability to } \\
\text { minimum food } \\
\text { requirement, } \lambda\end{array}$ & Sample size \\
\hline 1 & 21-24 May 2003 & Back-calculation & $0.27 \pm 0.05$ & $0.72 \pm 0.10$ & $12.0 \pm 2.2$ & 6.82 & 5 \\
\hline 2 & 11-14 June 2003 & Back-calculation & $0.17 \pm 0.11$ & $0.34 \pm 0.07$ & $18.4 \pm 4.8$ & 3.30 & 38 \\
\hline 3 & $\begin{array}{l}\text { 27-30 June } 2003 \\
18 \text { July } 2003\end{array}$ & $\begin{array}{l}\text { Back-calculation } \\
\text { Sampling }\end{array}$ & $0.10 \pm 0.06$ & $0.31 \pm 0.04$ & $24.0 \pm 4.2$ & 3.07 & $\begin{array}{l}50 \\
58\end{array}$ \\
\hline 4 & 6-9 May 2004 & Back-calculation & $0.16 \pm 0.09$ & $0.23 \pm 0.06$ & $17.5 \pm 5.1$ & 2.80 & 9 \\
\hline 5 & 18-21 May 2004 & Back-calculation & $0.15 \pm 0.08$ & $0.23 \pm 0.05$ & $19.7 \pm 5.5$ & 2.66 & 20 \\
\hline 6 & 6-9 June 2004 & Back-calculation & $0.17 \pm 0.11$ & $0.45 \pm 0.09$ & $18.8 \pm 5.9$ & 4.22 & 42 \\
\hline 7 & $\begin{array}{l}\text { 1-4 July } 2004 \\
6 \text { July } 2004\end{array}$ & $\begin{array}{l}\text { Back-calculation } \\
\text { Sampling }\end{array}$ & $0.09 \pm 0.03$ & $0.14 \pm 0.01$ & $26.7 \pm 4.0$ & 1.27 & $\begin{array}{l}18 \\
14\end{array}$ \\
\hline 8 & $\begin{array}{l}\text { 13-16 July } 2004 \\
6 \text { August } 2004\end{array}$ & $\begin{array}{l}\text { Back-calculation } \\
\text { Sampling }\end{array}$ & $0.09 \pm 0.04$ & $0.36 \pm 0.01$ & $28.7 \pm 1.3$ & 3.03 & $\begin{array}{r}6 \\
50\end{array}$ \\
\hline 9 & 9-12 May 2005 & Back-calculation & $0.26 \pm 0.17$ & $0.51 \pm 0.26$ & $11.8 \pm 6.3$ & 4.97 & 2 \\
\hline 10 & 19-22 Мay 2005 & Back-calculation & $0.27 \pm 0.15$ & $0.44 \pm 0.11$ & $12.0 \pm 3.6$ & 4.05 & 18 \\
\hline 11 & 6-9 June 2005 & Back-calculation & $0.13 \pm 0.09$ & $0.47 \pm 0.10$ & $18.6 \pm 4.4$ & 4.90 & 46 \\
\hline 12 & $\begin{array}{l}22-25 \text { June } 2005 \\
27 \text { June } 2005\end{array}$ & $\begin{array}{l}\text { Back-calculation } \\
\text { Sampling }\end{array}$ & $0.07 \pm 0.03$ & $0.24 \pm 0.03$ & $25.3 \pm 4.4$ & 2.55 & $\begin{array}{l}49 \\
50\end{array}$ \\
\hline 13 & 23-26 May 2005 & Back-calculation & $0.18 \pm 0.06$ & $0.22 \pm 0.04$ & $12.6 \pm 3.2$ & 2.24 & 15 \\
\hline 14 & $\begin{array}{l}\text { 13-16 June } 2006 \\
24 \text { June } 2006\end{array}$ & $\begin{array}{l}\text { Back-calculation } \\
\text { Sampling }\end{array}$ & $0.09 \pm 0.02$ & $0.23 \pm 0.01$ & $22.3 \pm 1.8$ & 2.56 & $\begin{array}{l}98 \\
98\end{array}$ \\
\hline
\end{tabular}

$C(l, m(i, l))=p \times C_{\mathrm{c}}(l, m(i, l)) \times W_{\mathrm{a}}(l, m(i, l))^{-1}$.

Metabolic

In the growth model of larval northern anchovy, the metabolic rate, assumed as a function of an organism's body mass and temperature, is

$R=0.187 \times W_{\mathrm{d}}^{0.834} \times \exp \left(\frac{\ln \left(Q_{10}\right)}{10} \times(T-16)\right)$,

where $R\left(\mu \mathrm{g} \mathrm{day}^{-1}\right)$ is the metabolic rate, $W_{\mathrm{d}}(\mu \mathrm{g})$ is dry body weight, $Q_{10}$ is defined as the increase in the rate of a physiological process resulting from a $10{ }^{\circ} \mathrm{C}$ increase in temperature, and $T\left({ }^{\circ} \mathrm{C}\right)$ is temperature [36]. We assumed a simple and standard formulation for the mass-specific metabolic rate $U(l, m(i, l))\left(\right.$ day $\left.^{-1}\right)$ of individual anchovy $l$ at $m(i, l)$ th ring formation of

$$
\begin{aligned}
U(l, m(i, l))= & 0.187 \times\left(W_{\mathrm{a}}(l, m(i, l)) \times \frac{10^{3}}{0.43}\right)^{0.834-1} \\
& \times \exp \left(\frac{\ln \left(Q_{10}\right)}{10} \times(T(i)-16)\right),
\end{aligned}
$$

where $10^{3} / 0.43$ is a multiplier to convert to carbon weight from dry weight. Urtizberea et al. [36] used the same $Q_{10}$ (=2.2) as in bay anchovy Anchoa mitchilli larvae [37].
We estimated $Q_{10}$ by the data fitting method (see "Estimation of parameters").

\section{Estimation of parameters}

The mass-specific growth rate of an individual for nonreproducing fish is predicted as the weight increment per unit weight per time and defined by the following equation [38]

$G=C-(M+F+E)$,

where the growth $G$ over a time period is the difference between energy gained through food consumption $C$ and the sum of energy costs and losses through metabolism $M$, egestion $F$, and excretion $E$. Metabolic costs are represented by standard metabolism $U$ and the cost of dynamic action SDA

$M=U+\mathrm{SDA}$,

as in Hansen et al. [39]. Values of $F, E$, and SDA in both the original and modified model were determined as

$F=0.104 \times C$,

$E=0.068 \times(C-F)$,

and 


\section{Copepod swimming speed}

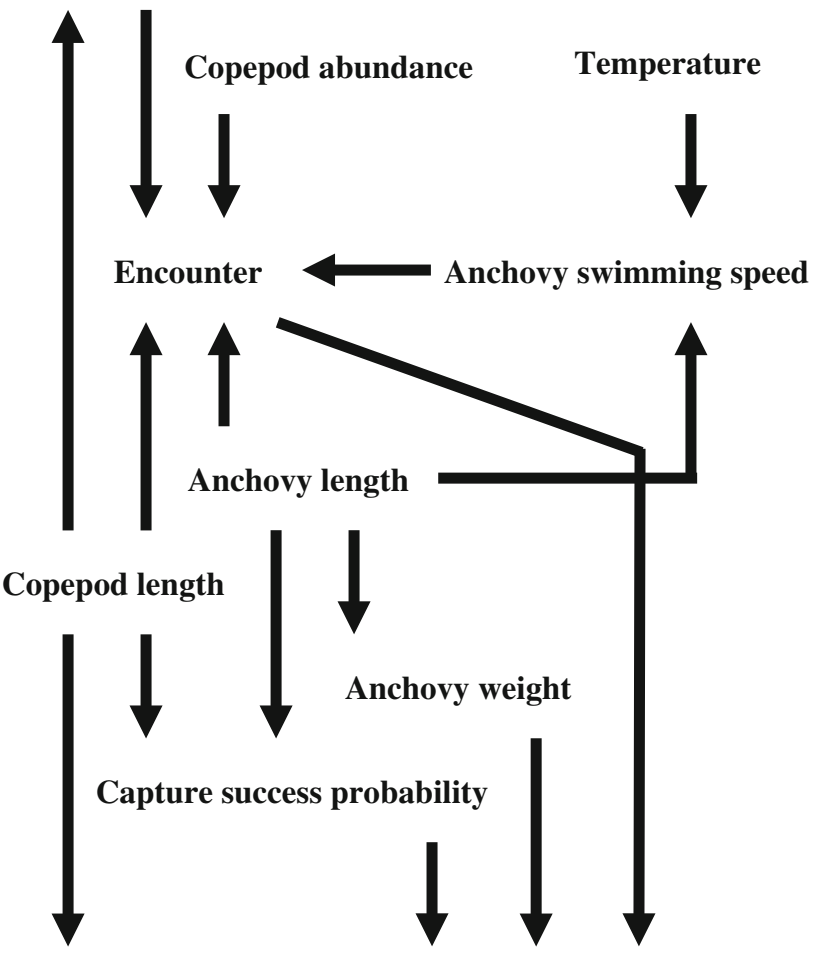

\section{Copepod weight $\longrightarrow$ Anchovy food availability}

Fig. 2 Flow diagram of the anchovy food availability calculation. Arrows indicate flow of data calculation

$\mathrm{SDA}=0.172 \times(C-F)$.

Substituting Eqs. 27-30 into Eq. 26,

$G=0.68 \times C-U$.

We assumed that the predicted mass-specific growth rate of each individual anchovy had an error term $z$, with a normal distribution

$G(l, m(i, l))=0.68 \times C(l, m(i, l))-U(l, m(i, l))+z$,

$z \sim N\left(0, \sigma^{2}\right)$

where $N\left(0, \sigma^{2}\right)$ is a normal distribution with mean zero and variance $\sigma^{2}$.

In the model, $p$ and $Q_{10}$ were estimated by minimizing the sum of squares

$\operatorname{SS}\left(p, Q_{10}\right)=\sum_{i} \sum_{l}(G(l, m(i, l))-\hat{G}(l, m(i, l)))^{2}$.

The least-squares minimization was performed by the quasi-Newton method in Solver add-in software for MSExcel (Microsoft Co. Ltd.). The least-squares minimization procedure was stopped if either of the two following conditions was satisfied: (a) More than 1000 iterations were attempted, or

(b) The sum of squared residuals changed by less than $0.01 \%$ between iterations.

Confidence intervals of the estimators were calculated through a likelihood ratio test. $\Theta=\left(\theta_{1}, \theta_{2}\right)=\left(p, Q_{10}\right)$ is a parameter vector, $\hat{\Theta}=\left(\hat{p}, \hat{Q}_{10}\right)$ is the estimated parameter vector which minimizes $\operatorname{SS}\left(p, Q_{10}\right)$, and $\Theta_{\mathrm{m}}\left(\Theta_{1}=\left(\theta_{1}, \hat{\theta}_{2}\right)=\right.$ $\left.\left(p, \hat{Q}_{10}\right), \Theta_{2}=\left(\hat{\theta}_{1}, \theta_{2}\right)=.\left(\hat{p}, Q_{10}\right)\right)$ is the parameter vector which minimizes $\operatorname{SS}\left(p, Q_{10}\right)$ with respect to the parameters except $\theta_{\mathrm{m}}$. The confidence interval for a certain parameter $\theta_{\mathrm{m}}$ was given as the region which satisfied the inequality

$2 \times \ln \left(\frac{L(\hat{\Theta})}{L\left(\Theta_{\mathrm{m}}\right)}\right) \leq \chi^{2}(0.95,1)$,

where $L$ is the likelihood:

$\ln (L(\Theta))=-\frac{n}{2} \times \ln \left(2 \times \pi \times \sigma^{2}\right)-\frac{1}{2 \times \sigma^{2}} \times \operatorname{SS}\left(p, Q_{10}\right)$,

and $\chi^{2}(0.95,1)$ is the $95 \%$ value of the $\chi^{2}$ distribution with one degree of freedom.

Food shortage

Supposing that the zero growth rate state was under the minimum food requirement condition, setting the left-hand side of Eq. 31 to zero, the minimum food requirement of anchovy $C_{\min }\left(\mathrm{mgC}\right.$ day $\left.^{-1}\right)$ was calculated by

$$
\begin{aligned}
C_{\min }= & 0.187 \times\left(W_{\mathrm{a}} \times \frac{10^{3}}{0.43}\right)^{0.834} \\
& \times \exp \left(\frac{\ln \left(Q_{10}\right)}{10} \times(T-16)\right) \times \frac{0.43 \times 10^{-3}}{0.68 \times p},
\end{aligned}
$$

where $W_{\mathrm{a}}(\mathrm{mgC})$ is the body mass of an individual anchovy of body length $L_{\mathrm{a}}$ calculated by Eq. 4 . If the food availability $C_{\mathrm{c}}\left(\mathrm{mgC} \mathrm{day}{ }^{-1}\right)$ is evaluated, then we can judge whether the anchovy was under food shortage or not by using the ratio of $C_{\mathrm{c}}$ to $C_{\mathrm{min}}$, namely

$\lambda=\frac{C_{\mathrm{c}}}{C_{\min }}= \begin{cases}<1 & \text { (as food shortage }) \\ \geq 1 & (\text { as not food shortage })\end{cases}$

We calculated $\lambda$ from the average mass-specific food availability, body length, and temperature for each cruise and investigated whether a food shortage for anchovy larvae occurred or not in Hiuchi-nada Sea in 2003-2006.

\section{Results}

We could carry out back-calculation of the anchovy massspecific growth rate, mass-specific food availability, and 
Table 4 Estimated parameter values and $95 \%$ confidence intervals (in parentheses) for the growth rate model equation

\begin{tabular}{lllll}
\hline Parameters & \multicolumn{2}{l}{$\sigma^{2}$} & Log $(L)$ & Sample size \\
\cline { 1 - 4 } & $Q_{10}$ & & & \\
\hline $0.86(0.83-0.89)$ & $2.11(1.49-2.85)$ & 0.0052 & 505 & 416 \\
\hline
\end{tabular}

SL in cruise $1-3$ in $2003,4-8$ in $2004,9-12$ in 2005 , and 13-14 in 2006 (Table 3). The range of average mass-specific growth rate, food availability, and SL was $0.07-0.27$, 0.14-0.72 day ${ }^{-1}$, and $11.8-28.7 \mathrm{~mm}$, respectively. The estimated growth model parameters $p$ and $Q_{10}$, their confidence intervals, the growth rate variance $\sigma^{2}$, and the lognormal likelihood are summarized in Table 4. The goodness of fit between $\hat{G}(l, m(i, l))$ and

$$
\begin{aligned}
G(l, m(i, l))= & 0.68 \times p \times C_{\mathrm{c}}(l, m(i, l)) \times W_{\mathrm{a}}(l, m(i, l))^{-1} \\
& -0.187 \times\left(W_{\mathrm{a}}(l, m(i, l)) \times \frac{10^{3}}{0.43}\right)^{0.834-1} \\
& \times \exp \left(\frac{\ln \left(Q_{10}\right)}{10} \times(T(i)-16)\right) \\
= & 0.58 \times C_{\mathrm{c}}(l, m(i, l)) \times W_{\mathrm{a}}(l, m(i, l))^{-1} \\
& -0.187 \times\left(W_{\mathrm{a}}(l, m(i, l)) \times \frac{10^{3}}{0.43}\right)^{0.834-1} \\
& \times \exp \left(\frac{\ln (2.11)}{10} \times(T(i)-16)\right)
\end{aligned}
$$

was significantly high (Fig. $3 ; r^{2}=0.36, P<0.001$ ). Regression analysis of predicted versus observed growth rates yielded a slope not significantly different from $1.0(t$ test, $P<0.05)$. A plot of the difference between the observed and predicted mass-specific growth rate $\hat{G}-G$ against the backcalculated anchovy length and mass-specific food availability is shown in Fig. 4. The difference tends to decrease with increasing length and mass-specific food availability,

$\hat{G}-G=-0.11 \times \ln (\mathrm{SL})+0.33 \quad\left(r^{2}=0.23, P<0.001\right)$,

$\hat{G}-G=-0.045 \times \ln \left(\frac{C_{\mathrm{c}}}{W_{\mathrm{a}}}\right)-0.021$

$\left(r^{2}=0.43, P<0.001\right)$.

The range of $\lambda$ was 3.07-6.82 in 2003, 1.27-4.22 in 2004, 2.55-4.97 in 2005, and 2.24-2.56 in 2006. Food shortage for anchovy larvae did not occur, although $\lambda$ in cruise 7 was close to the food shortage criteria value (Table 3).

\section{Discussion}

In this study, the estimated $Q_{10}$ value was close to the value for bay anchovy larvae. Kono et al. [10] reared larvae for

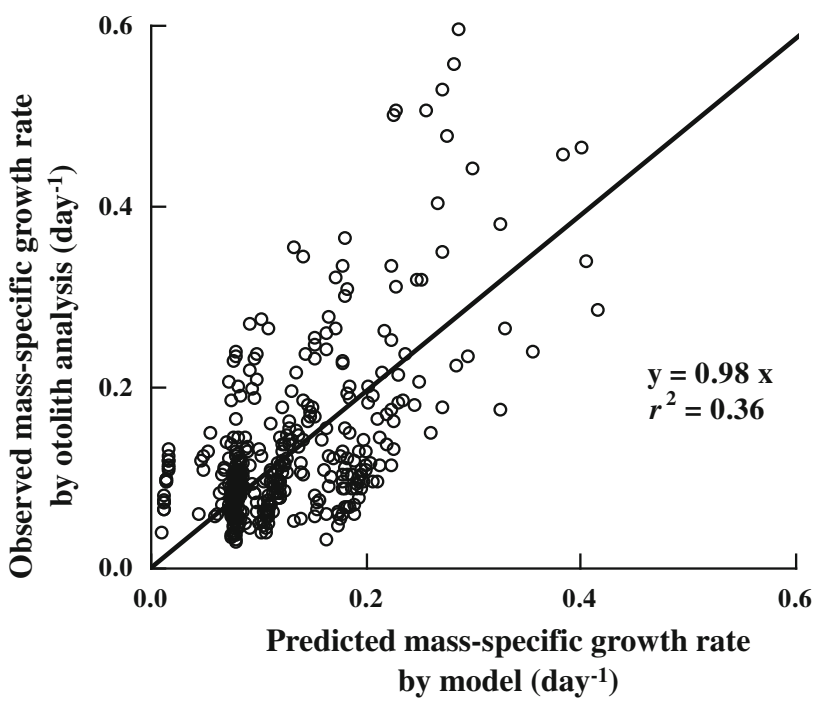

Fig. 3 Goodness of fit between observed mass-specific growth rate estimated from otolith analysis and predicted mass-specific growth rate calculated from model of anchovy

up to 9 days after the first feeding stage at 20 and $25^{\circ} \mathrm{C}$. At $20{ }^{\circ} \mathrm{C}$, the protein weight of larvae at 0,2 , and 3 days after first feeding day was 5.1, 3.8, and $2.8 \mu \mathrm{g}$, respectively, and at $25^{\circ} \mathrm{C}$, the weight of larvae at 0 and 2 days after first feeding day was 4.9 and $3.2 \mu \mathrm{g}$, respectively (after Fig. 4 in Kono et al. [10]). The mass-specific metabolic rate was calculated by the average decreasing rate in protein weight of unfed larvae reared at 20 and $25^{\circ} \mathrm{C}$. The mass-specific metabolic rate at $20{ }^{\circ} \mathrm{C}$ and at $25^{\circ} \mathrm{C}$ was $((5.1-3.8 \mu \mathrm{g}) /$ 2 days $/ 5.1 \mu \mathrm{g}+(5.1-2.8 \mu \mathrm{g}) / 3$ days $/ 5.1 \mu \mathrm{g}) / 2=0.14$ day $^{-1}$ and $(4.9-3.2 \mu \mathrm{g}) / 2$ days $/ 4.9 \mu \mathrm{g}=0.17 \mathrm{day}^{-1}$, respectively. Calculating the mass-specific metabolic rate by using the second term on the right-hand side of Eq. 39, the rate of 5.6-mm larvae at 20 and $25^{\circ} \mathrm{C}$ was 0.13 and 0.18 day $^{-1}$, respectively. The metabolic rate model adopted in this study should be appropriate, since the difference between the predicted and experimental value was small.

Most bioenergetics models for fish have indicated that feeding rates, i.e., Hewett-Johnson $p$ values, are around $0.3-0.4$ [40-42]. Urtizbera et al. [36] assumed that $p$ of northern anchovy increases from 0.42 to 0.78 , proportionally to body mass. In our model, the estimated $p$ value, 0.86 , was slightly higher than the typical value range. Brylawski and Miller [42] indicated that Hewett-Johnson $p$ values estimated for the blue crab Callinectes sapidus were different under different rearing conditions. Laboratory-reared crabs may have a low Hewett-Johnson $p$ value $(p=0.067)$ because the food quality is much higher than in nature $(p=0.35)$. Higher $p$ than the typical value indicates that the food quality for anchovy larvae in Hiuchi-nada Sea was lower than that for northern anchovy. However, this conclusion is not appropriate, since we could 


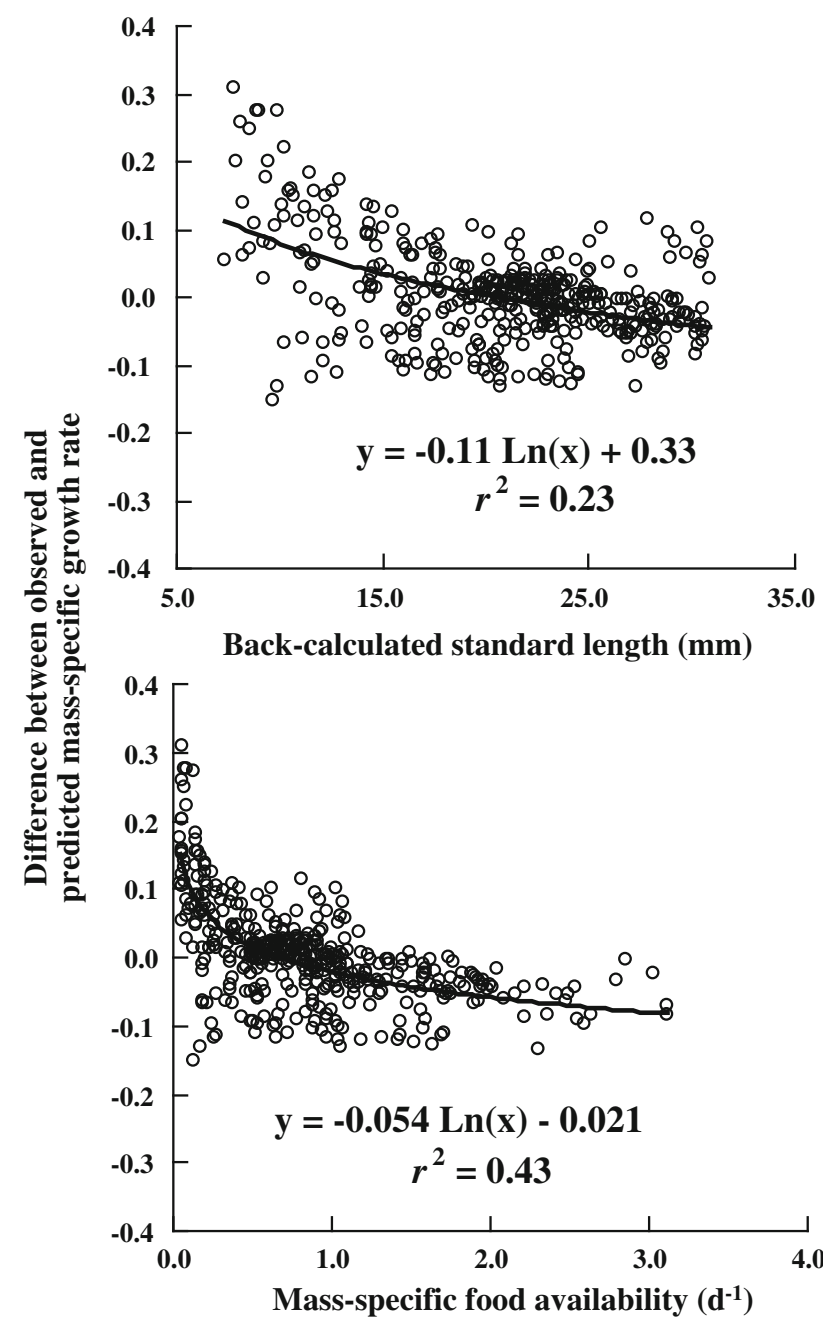

Fig. 4 Difference between the predicted and observed mass-specific growth rate against back-calculated anchovy length and mass-specific food availability

not provide the "true value" of food availability for anchovy larvae in Hiuchi-nada Sea. Yamashita et al. [43] indicated that the naked dinoflagellates Gyrodinium instriatum and Gymnodinium sanguineum play a supplementary role under natural conditions of low microzooplankton density to sustain better survival and growth of first-feeding larval anchovy. Copepods outnumbered the meso- and macrozooplankton community in Hiuchi-nada Sea, with average compositions of about 87-100 and 53-71\% in April and June [44], the relative importance of copepods in this area being high, while copepod nauplii were less numerous in the microzooplankton (tintinnids, naked ciliates, copepod nauplii, etc.) community in Hiuchinada Sea in April and June [45]. This suggests that prey organisms other than copepod nauplii are important for survival and growth of first-feeding anchovy larvae, too. In our modeling analysis, anchovy was assumed to eat only copepods, therefore the food availability for anchovy may be an underestimation. Moreover, our plankton survey did not consider the vertical distribution of copepod. When integrated over large spatial scales, estimates of prey abundance are generally considered to underestimate the effective concentrations of prey available to fish larvae [46]. We concluded that the estimation of food availability depends on the selected survey method and target prey organisms. In this study, the Hewett-Johnson $p$ value was just a proportional constant value and not an assimilation rate. The underestimated food availability will lead to a higher estimated Hewett-Johnson $p$ value, since there is a trade-off relationship between food availability and Hewett-Johnson $p$ value. This is the main cause of the high estimated Hewett-Johnson $p$ value in this study. Moreover, the growth model in this study underestimates the growth rate for smaller fish during the first-feeding stage or for low food availability (Fig. 4), and does not work well for larvae with SL smaller than about $10 \mathrm{~mm}$. The main cause might be underestimation of food availability for smaller anchovy due to the exclusion of microzooplankton other than copepod nauplii. However, work on identification of microzooplankton other than copepod nauplii requires experience and is time consuming. To evaluate the survival or food condition of anchovy larvae during the first-feeding stage, we recommend that the $0 \%$ growth criterion for RNA:DNA ratio be calculated against temperature [10].

The reproductive success rate (recruitment/larval abundance) in 2004 was lower than in 2003 and 2005 $\left(0.45 \times 10^{10} \mathrm{~m}^{3}\right.$ in 2003, $0.06 \times 10^{10} \mathrm{~m}^{3}$ in 2004, $1.62 \times 10^{10} \mathrm{~m}^{3}$ in 2005; Zenitani et al. [14]), and $\lambda$ in the last 10 days of May 2004 was 2.26, lower than in the last 10 days of May 2003 and 2005, but not close to values corresponding to food shortage. It was possible that the low food availability in the last 10 days of May led to the low reproductive success rate in 2004. Our results for the food shortage criterion in this study support the suggestion of Zenitani et al. [14] that "periods of the last 10 days of May to first 10 days of June was the crucial period for recruitment of anchovy in Hiuchi-nada Sea." Although the observed copepod density does not represent sufficient food availability for anchovy in some cases, the newly developed growth model is considered as optimal at present and useful to link environmental conditions and larval growth.

Acknowledgments We thank Dr. Tsukamoto, Mrs. Iguchi, Yoshida, Tani, Ueda, and Nakano for their kind assistance. We are also indebted to the captain and crew of the R.V. Shirafuji maru and company executives and staff of the Mekachi suisan Ltd. for their assistance with sampling. This work was supported in part by "Research for assessment and prediction of production rate in fishery ground," the Fisheries Agency and "Study for the prediction and control of the population outbreak of the marine life in relation to environmental change (POMAL)-Studies on prediction and control of 
Jellyfish outbreaks (STOPJELLY)," Agriculture, Forestry, and Fisheries Research Council (AFFRC).

Open Access This article is distributed under the terms of the Creative Commons Attribution License which permits any use, distribution, and reproduction in any medium, provided the original author(s) and the source are credited.

\section{References}

1. Takeoka H (1997) Comparison of the Seto Inland Sea with other enclosed seas from around the world. In: Okaichi T, Yanagi T (eds) Sustainable development in the Seto Inland Sea, Japan from the viewpoint of fisheries. Terra Scientific, Tokyo, pp 223-247

2. Zenitani H, Kono N, Tsukamoto Y, Masuda R (2009) Effects of temperature, food availability, and body size on daily growth rate of Japanese anchovy Engraulis japonicus larvae in Hiuchi-nada. Fish Sci 75:1177-1188

3. Heath MR (1992) Field investigations of the early life stages of marine fish. Adv Mar Biol 28:1-174

4. Mullon C, Freon P, Parada C, van der Lingen CD, Huggett J (2003) From particles to individuals: modeling the early stages of anchovy (Engraulis capensis/encrasicolus) in the southern Benguela. Fish Oceanogr 12:396-406

5. Parada C, van der Lingen CD, Mullon C, Penven P (2003) Modeling the effect of buoyancy on the transport of anchovy (Engraulis capensis) eggs from spawning to nursery grounds in the southern Benguela: an IBM approach. Fish Oceanogr 12:170-187

6. Allain G, Petitgas P, Lazure P (2007) The influence of environment and spawning distribution on the survival of anchovy (Engraulis encrasicolus) larvae in the Bay of Biscay (NE Atlantic) investigated by biophysical simulations. Fish Oceanogr 16:506-514

7. Kramer D, Zweifel JR (1970) Growth of anchovy larvae (Engraulis mordax Girard) in the laboratory as influenced by temperature. Calif Coop Ocean Fish Invest Rep 14:84-87

8. Tsuji S, Aoyama T (1984) Daily growth increments in otoliths of Japanese anchovy larvae Engraulis japonicus. Nippon Suisan Gakkaishi 50:1105-1108

9. Theilacker GH (1987) Feeding ecology and growth energetics of larval northern anchovy. Engraulis mordax. Fish Bull 85: 213-228

10. Kono N, Tsukamoto Y, Zenitani H (2003) RNA:DNA ratio for diagnosis of the nutritional condition of Japanese anchovy Engraulis japonicus larvae during the first-feeding stage. Fish Sci 69:1096-1102

11. Hunter JR (1972) Swimming and feeding behavior of larval anchovy Engraulis mordax. Fish Bull 70:1-834

12. Yokota T, Toriyama M, Kanai F, Nomura S (1961) Studies on the feeding habit of fishes (in Japanese). Rep Nankai Reg Fish Res Lab 14:1-234

13. Uotani I (1985) The relation between feeding mode and feeding habit of anchovy larvae (in Japanese). Nippon Suisan Gakkaishi 51:1057-1065

14. Zenitani H, Kono N, Tsukamoto Y (2011) Simulation of copepod biomass by a prey-predator model in Hiuchi-nada, central part of the Seto Inland Sea: Does copepod biomass affect the recruitment to the shirasu (larval Japanese anchovy Engraulis japonicus) fishery? Fish Sci 77:455-466

15. Geffen AJ (1982) Otolith ring deposition in relation to growth rate in herring (Clupea harengus) and turbot (Scophthalmus maximus) larvae. Mar Biol 71:317-326
16. Moksness E, Wespestad V (1989) Ageing and back-calculating growth rates of Pacific herring, Clupea pallasii, larvae by reading daily otolith increments. Fish Bull 87:509-513

17. Oozeki Y, Zenitani H (1996) Factors affecting the recent growth of Japanese sardine larvae (Sardinops melanostictus) in the $\mathrm{Ku}-$ roshio Current. In: Watanabe Y et al (eds) Survival strategies in early life stages of marine resources. Balkema, Rotterdam, pp 95-113

18. Zenitani H, Nakata K, Inagake D (1996) Survival and growth of sardine larvae in the offshore side of the Kuroshio. Fish Oceanogr 5:56-62

19. Fukuhara O (1983) Development and growth of laboratory reared Engraulis japonica (Houttuyn) larvae. J Fish Biol 23:641-652

20. Campana SE (1990) How reliable are growth back-calculations based on otoliths? Can J Fish Aquat Sci 47:2219-2227

21. Watanabe Y, Kuroki T (1997) Asymptotic growth trajectories of larval sardine (Sardinops melanostictus) in the coastal waters off western Japan. Mar Biol 127:369-378

22. Shoji J (2000) Early survival strategies of Japanese Spanish mackerel (Scomberomorus niphonius) in the Seto Inland Sea. $\mathrm{Ph} . \mathrm{D}$. Dissertation, Kyoto University, Kyoto

23. Uye S (1982) Length-weight relationships of important zooplankton from the Inland Sea of Japan. J Oceanogr Soc Jpn 38:149-158

24. Takahashi M, Watanabe Y (2004) Staging larval and early juvenile Japanese anchovy based on the degree of guanine deposition. J Fish Biol 64:262-267

25. Horiki N (1981) Vertical distribution of fish eggs and larvae in the Kii Channel (in Japanese). Aquiculture 29:117-124

26. Yamamoto K, Nakajima M, Tsujino K (1997) Vertical distribution of fish eggs and larvae in Osaka Bay (in Japanese). Bull Osaka Prefect Fish Exp Stn 10:1-17

27. Uye S, Nagano N, Tamaki H (1996) Geographical and seasonal variations in abundance, biomass and estimated production rates of microzooplankton in the Inland Sea of Japan. J Oceanogr 52:689-703

28. Liang D, Uye S (1996) Population dynamics and production of the planktonic copepods in a eutrophic inlet of the Inland Sea of Japan. III. Paracalanus sp. Mar Biol 127:219-227

29. Uye S, Aoto I, Onbe T (2002) Seasonal population dynamics and production of Microsetella norvegica, a widely distributed but little studied marine planktonic harpacticoid copepod. J Plankton Res 24:143-153

30. Kuwahara A, Suzuki S (1984) Diurnal changes in vertical distributions of anchovy eggs and larvae in the western Wakasa Bay (in Japanese). Nippon Suisan Gakkaishi 50:1285-1292

31. Gerritsen J, Strickler JR (1977) Encounter probabilities and community structure in zooplankton: a mathematical model. J Fish Res Bd Can 34:73-82

32. Bailey KM, Batty RS (1983) A laboratory study of predation by Aurelia aurita on larval herring (Clupea harengus): experimental observations compared with model predictions. Mar Biol 72:295-301

33. Van Duren LA, Videler JJ (1995) Swimming behavior of developmental stages of the calanoid copepod Temora longicornis at different food concentrations. Mar Ecol Prog Ser 126:153-161

34. Yen J (1988) Directionality and swimming speeds in predatorprey and male-female interactions of Euchaeta rimana, a subtropical marine copepod. Bull Mar Sci 43:395-403

35. Hewett SW, Johnson BL (1992) A generalized bioenergetics model of fish growth for microcomputers. University of Wisconsin Sea Grant Institute Tec Rep WIS-SG-91-250, Madison

36. Urtizberea A, Fiksen Ø, Folkvord A, Irigoien X (2008) Modeling growth of larval anchovies including diel feeding patterns, temperature and body size. J Plankton Res 30:1369-1383 
37. Houde ED, Schekter RC (1983) Oxygen uptake and comparative energetics among eggs and larvae of three subtropical marine fishes. Mar Biol 72:283-293

38. Kitchell JF, Stewart DJ, Weininger D (1977) Applications of a bioenergetics model to yellow perch (Perca flavescens) and walleye (Stizostedion vitreum vitreum). J Fish Res Board Can 34:1922-1935

39. Hansen MJ, Boisclair D, Brandt SB, Hewett SW, Kitchell JF, Lucas MC, Ney JJ (1993) Applications of bioenergetics models to fish ecology and management: where do we go from here? Trans Am Fish Soc 122:1019-1030

40. Kershner MW, Schael DM, Stein RA, Marschall EA (1997) Modeling sources of variation for growth and predatory demand of Lake Erie walleye (Stizostedion vitreum), 1986-1995. Can J Fish Aquat Sci 56:527-538

41. Yako LA, Mather ME (2000) Assessing the contribution of anadromous herring to largemouth bass growth. Trans Am Fish Soc 129:77-88
42. Brylawski BJ, Miller TJ (2003) Bioenergetic modeling of the blue crab (Callinectes sapidus) using the fish bioenergetics (3.0) computer program. Bull Mar Sci 72:491-504

43. Yamashita Y, Ishimaru T, Kawaguchi K (1989) Survival and growth of first-feeding Japanese anchovy larvae fed with two species of naked dinoflagellates (in Japanese with English abstract). Nippon Suisan Gakkaishi 55:1029-1034

44. Uye S, Shimazu T (1997) Geographical and seasonal variations in abundance, biomass and estimated production rates of meso- and macrozooplankton in the Inland Sea of Japan. J Oceanogr 53:529-538

45. Uye S, Nagano N, Tamaki H (1996) Geographical and seasonal variations in abundance, biomass and estimated production rates of microzooplankton in the Inland Sea of Japan. J Oceanogr 52:689-703

46. Houde ED (2002) Mortality. In: Fuiman LA, Werner RG (eds) Fishery science the unique contributions of early life stage. Blackwell Science, Oxford, pp 64-87 